\title{
THE EFFECTIVENESS OF COLLABORATIVE BRAINSTORMING TRAINING PROCEDURES AT PRE-WRITING STAGE IN INTERMEDIATE ENGLISH CLASSES
}

\author{
Tran Thi Anh Tuyet* \\ Faculty of English, VNU University of Languages and International Studies, \\ Pham Van Dong, Cau Giay, Hanoi, Vietnam
}

Received 10 February 2017

Revised 27 September 2017; Accepted 29 November 2017

\begin{abstract}
This article reports a qualitative action study that emerged from the author's reflective teaching practice in an intermediate English class. The research investigated the effectiveness of collaborative brainstorming training procedures on students' ideas expressed in their written papers and on students' learning of writing skills through in-depth interviews, classroom observations, students' written papers and students' journals. The study indicates that collaborative brainstorming training with additional brainstorming rules can significantly improve quantity and quality of ideas in paragraph writing, but not remarkably in letter writing. Besides, training has had positive effects on students' learning of writing skills. The findings of the study, therefore, make important contributions to the implementation of collaborative brainstorming in the English language teaching practice.
\end{abstract}

Keywords: brainstorming, collaborative/ group brainstorming, writing skills, brainstorming rules

\section{Introduction}

\subsection{Rationale}

To intermediate level, writing skills were becoming more challenging to students as besides familiar writing forms like letters, they needed to learn new types like stories, film reviews and articles. The author and several colleagues shared in a teacher meeting that a lot of students had difficulties generating ideas and/or arranging ideas logically for their writing. In fact, the researcher had suggested and discussed ideas for writing topics with the whole class. However, through the researcher's observations, this technique did not have much effectiveness on improving idea generation and organization in student's writing. When she discussed with the students, several students suggested that they should be provided with more chances

* Tel.: 84-976931870

Email: tuyetthianhtran@gmail.com to work with their peers before consulting the teacher.

From reflective teaching practice, the researcher read about idea generation in groups, and became interested in group brainstorming. Brainstorming allows writers to quickly generate a large numbers of ideas and have good ideas to write because students can create lists of words or ideas related to a topic, and then choose ideas for their writing (Berne, 2009). However, some researchers argue that group idea generation could be less effective than individual (Mullen et al, 1991). Many studies had been carried out to explain for the productivity loss in this type of group work and to search for solutions (Diehl \& Stroebe, 1987; Mullen et al, 1991; Brown \& Paulus, 1996; Brown \& Putman, 2006; Putman \& Paulus, 2009). Especially, there was a module to train people to generate more ideas and higher quality of ideas in problem 
solving (Baruah \& Paulus, 2008). Regarding training students to generate ideas for writing topics, the researcher supposed that there would be similarities to the literature of group brainstorming, yet changes should be made to suit the students and the teaching context.

With all reasons above, the researcher developed procedures to train her students on collaborative brainstorming, and investigated influences of collaborative brainstorming on the ideas expressed in their writing. The training sessions and the techniques were applied in letter and paragraph writing, two genres of writing at this level.

\subsection{Research questions}

1. How does collaborative brainstorming influence the quality and quantity of ideas in students' writing?

2. How do students perceive the effectiveness of collaborative brainstorming activities?

\section{Literature review}

For decades, people have used brainstorming to generate ideas, and to come up with creative solutions to problems. One among such solutions came from Madison Avenue advertising executive Alex Osborn who developed the original approach to brainstorming (Osborn, 1953). Since then, brainstorming has been a popular activity in many organizations and in various fields for generating ideas (Paulus, 2000).

In language learning, specifically writing, Bauer (2009) states that brainstorming is the way a writer visually organizes information for the writing. It expresses free associations with the topics through words, phrases or possible perspectives. In brainstorming, the writer conducts exploration of the topic, and it offers several advantages.

\subsection{The advantages of collaborative brainstorming}

Brainstorming is considered a useful strategy to prepare learners to write (Berne,
2009). Brainstorming could be applied individually or collaboratively. However, some literature has revealed that the effectiveness of collaborative brainstorming on idea productivity should be taken into consideration (Diehl \& Stroebe, 1987; Diehl \& Stroebe, 1991; Mullen et al, 1991; Paulus et al, 1995; Nijstad \& Stroebe, 2006, Brown \& Paulus, 2002; Putman \& Paulus, 2008).

Many researchers believe that collaborative brainstorming could improve idea productivity (Osborn, 1963; Paulus et al, 1998; Baruah \& Paulus, 2008). It is explained that collaborative brainstormers can benefit from different perspectives and abilities of their peers because people in a group can cognitively stimulate each other to generate ideas and group members can support each other to produce more ideas.

\subsection{The drawbacks of collaborative brainstorming}

Despite advantages mentioned above, a number of researchers have found that collaborative brainstorming could lead to idea productivity loss due to at least four following factors: free riding, evaluation apprehension, production blocking and performance matching. First, free riding occurs when group members feel that their individual contributions to the group are less significant than when they work alone (Diehl \& Stroebe, 1991). Hence, the feeling that their ideas add little to the group outcome demotivates group members to produce ideas. Moreover, in collaborative brainstorming, brainstormers may not be confident or comfortable to speak out their ideas because of their concern about possible evaluations of their peers (Diehl \& Stroebe, 1991). In this case, evaluation apprehension can limit their contributions to the group, which causes group productivity loss. The next factor is production blocking that refers to opportunities for group members to raise their ideas. In group, one member can speak at a time; 
but when waiting for their turn, people may forget the ideas that have previously occurred in their mind. If a person tries to keep the ideas in his/her mind, he/she may not think of further ideas. Both individual and group productivity in idea generation will be reduced as a result of this (Diehl \& Stroebe, 1991). Last, performance matching is the comparison of performance level of group members. When brainstorming in a group, individuals may not want to outperform others (Brown \& Paulus, 1996). Therefore, they may decrease their performance of raising their ideas if they perceive that other members are not working as hard as they are. Consequently, the group productivity may be affected. These factors are of high importance to understand the nature of collaborative brainstorming, and to find how to improve group brainstorming techniques accordingly.

2.3. Solutions to improve the effectiveness of collaborative brainstorming

There have been several solutions to improve collaborative brainstorming including (1) sequencing individual brainstorming and group brainstorming, (2) brainwriting, (3) electronic brainstorming, (4) training sessions on group brainstorming and (5) adding more rules to group brainstorming.

\subsubsection{The sequence of individual and group brainstorming}

Osborn (1957) believes that effective brainstorming should consist of individual and group sessions. Osborn (1963) proposes that the best order may be working individually before working in group. In fact, there have been different perspectives on the effectiveness of the sequence of the two sessions (Baruah \& Paulus, 2008).

On the one hand, many researchers believe that the order of group to individual brainstorming session is effective. For instance, Dunnette, Campbell and Jastaad (1963) support that this sequence is best to enhance generation of ideas. That is because ideas and unexpected associations generated in groups can suggest additional ideas to individuals (Nagasundaram \& Dennis, 1993). Furthermore, data from a study of Paulus et al (1996) show that group brainstorming before individual brainstorming on the same topic can produce more ideas than the reverse process. The reason is that collaborative brainstormers are facilitated cognitively and this facilitation continues to the individual session when brainstormers generate ideas without production blocking (Brown \& Paulus, 2002). Brown and Paulus (2002) also find that a person who brainstorms collaboratively to individually can generate more ideas than a similar person brainstorming in two individual sessions. Therefore, according to these studies, the order group to solitary brainstorming could be more useful.

However, some other research reveals converse findings about this sequence. Stein (1975) claims that the individual-tocollaborative brainstorming sequence is best because it allows individuals to prepare for the group session by first generating and reflecting on their own ideas. Baruah and Paulus (2008) conduct an experiment and its results indicate that the sequence solitary to group brainstorming could be effective to improve quantity of ideas generated in group. They explain from the theory that because people brainstorming individually can generate more ideas than brainstorming in group, the pace of solitary session may be maintained in the group session. If the sequence is group to individual, the slower pace of generating ideas in group might affect the pace of the subsequent session. Therefore, the sequence individual brainstorming to group brainstorming is better in terms of number of ideas (Baruah \& Paulus, 2008).

\subsubsection{Brainwriting}

A solution to production blocking, one of the factors that lead to productivity loss in 
collaborative brainstorming (Diehl and Stroebe, 1987), is that group members brainstorm by writing and reading instead of speaking and listening. This way of brainstorming is called brainwriting (Brown and Paulus, 2002). When each member of a group of brainstormers in turn writes his/her ideas on a piece of paper without verbal interaction, group members may not be distracted. However, brainwriting is not often a choice because people tend to communicate orally in face-to-face contexts (Brown and Paulus, 2002). In addition, if individuals do not intend to read or do not have chances to read other people' ideas, brainwriting will not be beneficial to them (Brown and Paulus, 2002).

\subsubsection{Electronic brainstorming}

Electronic brainstorming is the way individuals brainstorm by typing ideas on networked computers. Brainstormers can write their ideas and see others' ideas without oral or face-to-face interactions among group members. Electronic brainstorming is believed to increase quantity of ideas generated because production blocking is greatly reduced (Brown \& Paulus, 2002). Brown and Paulus (2002) also argue that the sequence solitary to group brainstorming might result in better idea generation in groups doing electronic brainstorming.

\subsubsection{Training on idea generation in group}

Further to studying brainstorming procedures, Baruah and Paulus (2008) conduct a research on the effects of training on idea generation in group. In fact, that study investigates the effects of training and the sequence of individual and collaborative brainstorming sessions on idea generation (Baruah \& Paulus, 2008). Participants are divided into groups of individual brainstormers and collaborative brainstormers. Then they participate in either training or no-training on idea generation sessions. In the study, the participants in the individual-to-collaborative sequence produce more ideas than those in the collaborative-toindividual sequence. The results indicate that training can increase quantity of ideas generated in groups and that group brainstorming session preceded by solitary one can be effective (Baruah \& Paulus, 2008).

\subsubsection{Additional rules}

Putman and Paulus (2009) carry out a study on additional rules in group brainstorming. Besides the Osborn rules, some rules are added to better interaction. The additional rules are as follows: "stay focused on the task; do not tell stories; do not explain ideas; keep people talking, possibly by bringing up previous ideas; encourage others to contribute" (Putman \& Paulus, 2009, p. 24). These additional rules are found to be able to encourage group brainstormers to generate more ideas (Putman \& Paulus, 2009).

In this research (2009), Putman and Paulus study the effects of additional rules on group brainstorming through comparing two groups (groups of individual brainstormers vs collaborative ones) by two (Osborn vs additional rules). The participants brainstorm on the topic "ways to improve the university". Two of the significant results are that the groups given the additional rules generate more ideas than those who are given only the Osborn rules, and the type of rule hardly affects the idea quality.

From the study, it is seen that the additional rules can increase brainstorming performance in terms of quantity of ideas, which is an important effect of the rules. Indeed, these rules help keep participants highly concentrate on the task. The rule "do not tell stories" eliminates extra talking time among group members, and "do not explain ideas" saves time for other ideas rather than specifically focus on one idea. The last two rules "keep people talking" and "encourage others to contribute" aim at maintaining interaction and contribution among group members. Through the rules, more opportunities are created for group members to raise ideas. Also, the roles of group members in sharing ideas are more significant. Therefore, the rules contribute to 
reducing some factors that lead to productivity loss in group brainstorming like free riding, evaluation apprehension and blocking (Diehl \& Stroebe, 1987). The research is evidence that additional rules enhance the effectiveness of collaborative brainstorming.

In conclusion, there have been explanations for productivity loss in group brainstorming, and researchers have found five main ways to improve group brainstorming: sequencing individual sessions and group brainstorming ones, writing ideas rather than talking (brainwriting), using computers to brainstorm (electronic brainstorming), training for idea generation skills and adding some rules.

\section{Research methodology}

\subsection{Research design}

The study is action research aiming at training students to improving idea generating, planning and organizing at pre-writing stage.

\subsection{Participants}

The participants in the study included 20 non-majored English students ( 18 females and 2 males) who were learning at intermediate level in a class at VNU University of Social Sciences and Humanities and the teacher was also the researcher.

\subsection{Research instruments}

Students'written papers (pre-intervention and post-intervention)
For each type of writing, the researcher had students' pre-intervention and post intervention written papers. To be specific, before training, students wrote individually on a topic and after training, students wrote individually on a different topic. These two papers would be analysed and compared to investigate the effects of training procedures.

\section{Students' journals}

Each student wrote a journal about 100 words in Vietnamese to reflect on activities in training procedures. Students could use some suggestion questions that the researcher gave.

\section{Classroom observations}

A colleague was invited to observe the class and take notes of the process. Before the observation day, the researcher discussed with her about the research plan and the lesson plan when the process took place.

While training procedures were applied in class, a recorder was placed in each group to record students' activities.

\section{Interviews}

After training, interviews were conducted with nine students to find out students' perspectives on influences on group brainstorming activities. The colleague was also interviewed to reflect on the process.

\section{Training procedures}

Below is summary of a training procedure.

Table 1 . Summary of a training procedure

\begin{tabular}{ccc}
\hline & Activities & Time (minutes) \\
\hline Part 1 & Group setting & 5 \\
\hline \multirow{2}{*}{ Part 2 } & Group brainstorming practice 1 & \\
& Step 1: Solitary brainstorming & 5 \\
& Step 2: Group brainstorming & 10 \\
\hline \multirow{2}{*}{ Part 3 } & Group brainstorming practice 2 & 5 \\
& Step 1: Solitary brainstorming & 10 \\
\hline Part 4 & Step 2: Group brainstorming & 15 \\
\hline Part 5 & Actual brainstorming for the writing test & 25 \\
\hline & Writing for the test & 75 \\
\hline
\end{tabular}


This training procedure was based on the results of a study carried out by Baruah and Paulus (2008) that training could enhance the quatity and quality of ideas generated in group and the sequence of individual to group brainstorming session could be useful. Baruah and Paulus (2008) carried out the research to examined how training sessions and the sequence of individual to group (or group to individual) brainstorming affected the quality and quantity of ideas generated in brainstorming solutions to problems. In Baruah and Paulus (2008)'s study, the quality of ideas was measured on the originality of ideas, and quantity was measured on the number of ideas generated in an amount of time. The author applied the results of that study. However, she did not aim at training students to brainstorm ideas for problem solving, but she created writing topics that were familiar with the students in learning English. She would investigate how useful group idea generation was to her students in learning writing in English. This was the new point of the training procedures, as they were implemented in the context of the English language teaching and learning.

Part 1: Firstly, students were divided into groups of three or four by the teacher. Strong, average and weak students were mixed so that in group work they could assist one another.

Part 2 \& Part 3: These two parts were for students to practise group brainstorming. There was a topic for a part in which students brainstormed individually and then came to group discussion. When brainstorming alone, students were asked to note down as many ideas as possible, and students were told to follow the rules:

- work individually, do not discuss with other people;

- use simple words or phrases, not necessarily complete sentences;

- do not worry about grammar or spelling;
- write in English, but could use Vietnamese if necessary;

- write as many ideas as possible.

When coming to group brainstorming, students brought their paper to discuss with their partners. Each group would write down their ideas on another sheet of paper. During this process, students could discuss verbally with each other. In this session, students were reminded of the rules and asked to follow additional rules. All the rules were as follows:

- feel free to offer any ideas;

- generate as many ideas as possible;

- do not criticize any ideas of others;

- can combine and improve previous ideas;

- stay focused on the task: do not tell stories;

- give chances for every group member to express their ideas;

- $\quad$ with ideas you find strange (or unique), you may ask others to clarify;

- use simple words or phrases, not necessarily complete sentences;

- not to worry about grammar or spelling;

- use English, but could use Vietnamese if necessary.

Several rules were added to the brainstorming process aiming at supporting the students to increase the number of ideas and be able to benefit from peers' ideas. For example, if students did not understand other people's ideas, they could ask for clarification. This rule made members pay more attention to others' ideas and understand more about others' perspectives (Brown \& Paulus, 2002). The other rules related to language used to express ideas could help students feel free and be more focused on generating ideas.

At the end of part 3, teacher discussed with the students on the ideas for the two topics, and reminded students of the rules. Students were also told that they were going to brainstorm for another topic which was for writing. 
Part 4: Students did group brainstorming for the topic of the writing test. The same sequence was followed, individual to group brainstorming.

Part 5: Students used the ideas to write about the topic.

In one procedure, after the students were trained on group brainstorming, they did real practice on group brainstorming and did a written test.

\subsection{Data analysis}

Sorting and categorizing data

The collected data were classified according to the research questions. To be specific, the answer for the first question was found through the students' pre- vs. post-intervention written papers, students' journals and interviews. The second question was answered based on the triangulation of students' journals, observations, and interviews with the students.

All the interviews were transcribed verbatim. In reporting the results, data from the interviews, students' journals and observations were translated into English by the researcher with no intention of producing grammatical errors.

Analyzing data for meaning

As for the first questions, students' pre-intervention written papers and postintervention ones were compared. Quantity of ideas was measured through counting the ideas in students' writing; quality of ideas was compared based on two IELTS writing marking criteria including Task Response and Coherence and Cohesion. Tables were formed to compare quantity and quality of ideas of each student to see if there were changes after training procedures. Then, charts were formed to describe the remarkable results of the whole class. In addition, the researcher analysed student's journals and interviews to check reliability of the results of comparing the two student's written papers.
As for the second question, students' perspectives on the effects of the activities were analyzed on how well they worked with their group, how the activities prepared them to write and other benefits or effects of group brainstorming as pre-writing activities. Tables were formed to illustrate the ideas of students. Besides, the results were compared with the observations for consistency.

\section{Results and discussion}

4.1. Research question 1: How does collaborative brainstorming influence the quality and quantity of ideas in students ' writing?

\subsubsection{Paragraph writing}

\section{Quantity of idea}

Performance in terms of number of ideas was measured by counting the number of main ideas and supporting ideas in each student's written paper. There were two sets of students' written papers: pre-intervention papers when students wrote a paragraph about "How to stay healthy" and post-intervention ones when students wrote about "Possible reasons for the break-up of a love" after being trained with group brainstorming activities. The Mean (M) was accounted to compare the average number of ideas in the two papers. The High shows the highest number of ideas and the Low shows the lowest number of ideas in students' papers. The results are showed in the following charts: 


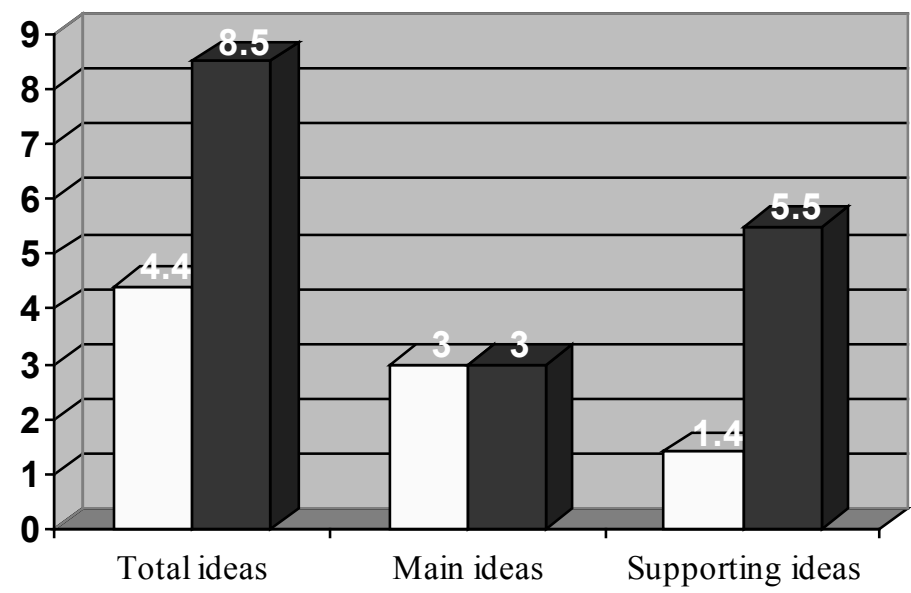

$\square$ Pre-intervention (no training)

Post-intervention (training)

Figure 1. Average number of total ideas, main ideas and supporting ideas in paragraphs in students' written papers

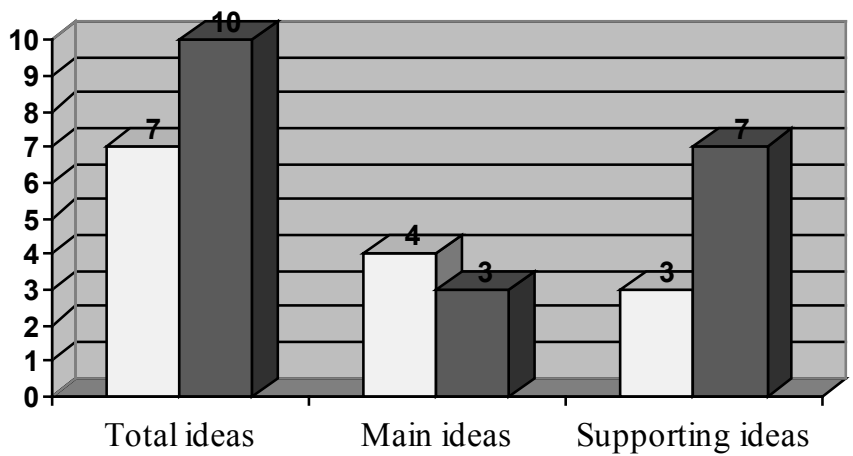

$\square$ Pre-intervention (no training)

$\square$ Post-intervention (training)

Figure 2. The highest number of ideas (High) in paragraphs in students' written papers

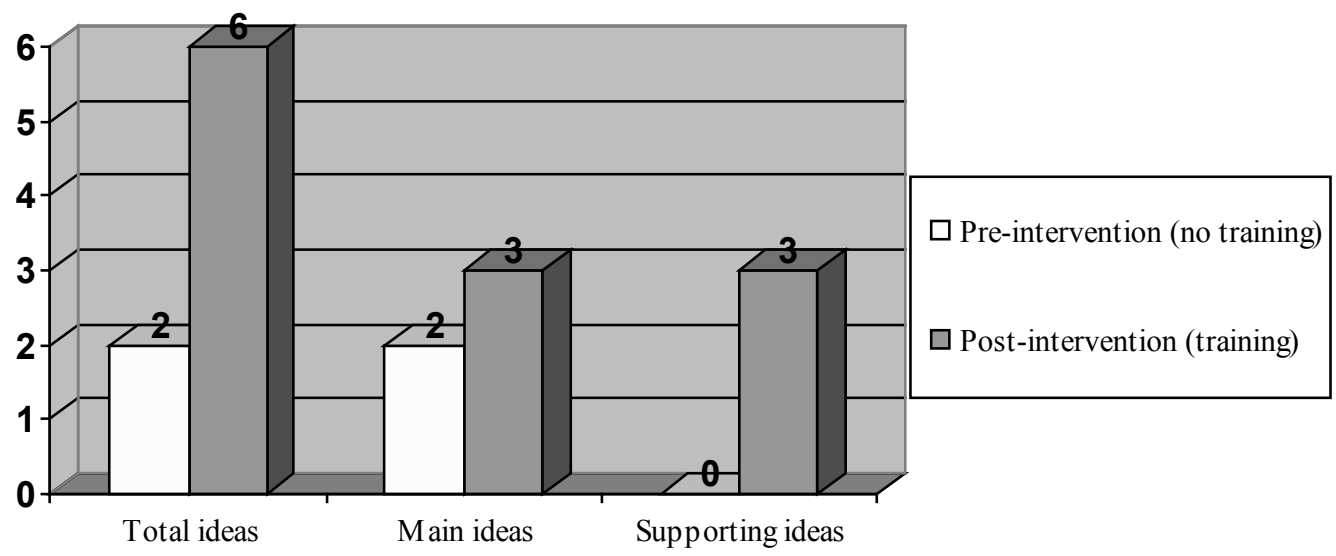

Figure 3. The lowest number of ideas (Low) in paragraphs in students' written papers

It is seen from the charts that there was a significant improvement in the number of ideas in post-intervention writing.
The average numbers of main ideas converge in both writing $(\mathrm{M}=3)$ which means that on average students could write three 
main ideas for the topic. However, in the first topic, there was difference in number of main ideas among students while in the second topic there is no difference. Concerning the first writing, some students (six students) produced four main ideas while others (seven students) just had two (High $=4$, Low $=2$ ). In the second topic, all students wrote three main ideas for the topic. Though there were a lot of ideas generated and written in the group brainstorming notes, students selected just some of them for writing.

In terms of supporting ideas, students in the class produced more ideas (approximately four times) in the second topic than the first one, with $\mathrm{M} 2=5.5$ versus $\mathrm{M} 1=1.4$. The difference between the number of ideas among each student was not so remarkable. However, it was worth noting that in the first topic, some students (four students) did not write any supporting ideas $($ Low $=0)$ but in the second one, students wrote at least three ideas $($ Low $=3)$. These figures of supporting ideas showed that students could make a progress in developing details for the writing topic.

In general, after training and working in group, students improved their performance in terms of the number of ideas in their written papers $(\mathrm{M} 1=4.4$ vs. $\mathrm{M} 2=8.5)$.

However, the two writing topics were different (the first was "how to stay healthy" and the second was "possible reasons for the break-up of a love"), so the better performance in the number of ideas in written papers was not sufficient to show that group brainstorming activities were effective on improving number of ideas. The reason was that idea generating capacity of each person could vary on different topics. For example, the second topic might be more interesting to the students, and they could generate more ideas to write. If a single topic was used for two times of writing, the capacity of generating ideas would also vary on different times. Therefore, students' comments in their journals and post-interviews were analyzed to check the influences of group brainstorming activities on the number of ideas in paragraph writing.

Interestingly, students commented that working in group brought more ideas. Some typical comments were as follows:

"I can share my ideas and other members in the group also share their ideas, which helps us to have much more ideas than working individually" (Tung Anh - Journal) "When working alone, the number of ideas will be limited; while working in group, there will be a lot of ideas for a topic. When brainstorming on a topic together, all members in my group have chances to contribute ideas. These ideas may be the same or different, and the group have more ideas" (Ninh - Journal).

"All members work together to develop ideas for the writing" (Tinh - Interview)

"When working in group, all members in my group are eager to contribute ideas, so we have lots of ideas" (Ly - Interview)

As seen above, students explained why working in group helped them to have a lot of ideas. For example, according to Tung Anh, Ninh and Tinh, more people could help to increase the number of ideas. In addition, from Ly's opinion, it can be seen that groupwork could stimulate members to contribute ideas.

More important than the increased total number of ideas generated in a group, individuals benefited from working in group in terms of building more ideas for themselves:

\footnotetext{
"I can have more ideas from ideas of others in the group. Sometimes, the ideas of other people help me to think of other ideas." (Trang - Journal)
} 
"When brainstorming together, I can share my ideas and listen to ideas of other members in my group, which is very good to develop ideas for my writing." (Nhung - Interview)

"When brainstorming in group I have opportunities to share my ideas with my peers. It helps me to learn ideas from other people. Therefore, group brainstorming helps me to write more easily because I have time to develop ideas before writing." (Hue - Journal)

"I can share my ideas with other group members and if my ideas are not clear enough for the topic, my peers can help to clarify. Such group work makes me write better with more ideas and vocabulary" (Hanh - Journal)

With the rule "write ideas in English, but could use Vietnamese if necessary", students were free to generate and wrote down as many ideas as possible. This was also the reason why some students spoke out ideas in Vietnamese and discussed in Vietnamese. In fact, students in a group told each other to write in Vietnamese:

"...uhm how to say "vì người kia thay đổi” - I don't know, just write the idea down first" (Recording - group 3)

"Who knows "không hợp/ ở xa" in English? - May be "not suitable/ far", just write both Vietnamese and English and check later" (Recording - group 1)

In group 3, when a student asked for the English expression of "vì người kia thay đổi" [because a person changes], the other student did not know and told her to write the idea in Vietnamese. In group 1, a student guessed how to express the idea in English, but she was not sure so she decided to write the idea in both Vietnamese and English. By doing this, the original idea was maintained and its translation was kept as well. This helped to save time, save the ideas and increase the number of ideas for the whole group.

However, the ideas of students in writing could be influenced by the teacher's changed instructions. In fact, in the second writing test, students asked how to write the paragraph from lots of ideas generated in group, and the teacher told the students to select three to five ideas that they thought were more important or easier to develop or simply they prefered and explained why. Then, they took one piece of blank paper and folded it into three to five parts corresponding with the number of ideas they had chosen. They would write each chosen idea in a part of the paper. In paragraph writing, these ideas would be main ideas and they needed to think of supporting details to fill in the blank after each main idea. When developing the training procedures, the teacher did not intend to guide students to select ideas. However, in real teaching, as students asked, the teacher decided to add more instructions for students to write. In fact, in real teaching practice, teachers can make changes to lesson plans. Hence, the implementation of the techniques is appropriate with teaching methodological theories.

The changed instructions were also noted by the critical colleague, and in interview, the researcher and she discussed the effects of changed instructions. In fact, the changed instructions might have some positive effects on students' writing performance. First, students were guided to select the number of ideas to write among many ideas generated. For example, in paragraph writing lesson, the lowest number of reasons for the break-up of a love generated in group was twelve and the highest was eighteen. Being asked to select ideas, students would pay more attention to the ideas and tend to use the selected ideas for writing afterwards. Second, students were asked to support main ideas with more details. By folding a blank piece of paper into corresponding parts and writing each main 
idea selected in a part, it would be clearer that they needed to write supporting ideas in each part of the paper. Therefore, the techniques helped clarify ideas for students to make their choice to write, and facilitated them to produce supporting details.

To sum up, training with group brainstorming activities before writing could increase the number of ideas in individual's written papers. Despite two different writing topics, the analysis of pre-intervention written papers and post-intervention ones, observations, students' journals and interviews indicated that the number of ideas was improved, and the teacher's additional instructions might contribute to the improvement.

\section{Quality of ideas}

The quality of ideas in students' written papers was measured on idea development criteria including Task response, coherence and cohesion on IELTS writing marking scheme for task 2 . From the analysis, there were two improvements on quality of ideas in the second written papers: the main ideas are identified more easily and the main ideas are better supported and more organized.

For the first topic, it could be difficult to identify main ideas in some students' written papers. The ideas were identified through some key words in the sentences. For example, in Hoa's paper, the first idea of staying healthy was 'I cook is healthy, eatn't food has fat, fast food and eat vegetable, meat, fish". The idea of eating healthy food was expressed through some words like "healthy... eat vegetable". In Ninh's paper, she wrote "I allway action for good healthy as: go to walk or play sport". Based on "go to walk or play sport", the reader could understand her idea of doing exercise for good health. Another example was Ngoc Ninh's paper when she wrote "you should have entertain time". This was the idea of spending time relaxing or entertaining, which was guessed based on "entertain time".
However, in other written papers (four papers), there were some good main ideas, which were clear and closely related to the topic. For instance, Ly wrote "you should exercise for 20 minutes every morning or afternoon" and "you should have the time relax after the work or school". Tung Anh also explained quite clearly in his writing "You must eat fresh food and don't eat too much the fast food.", and "You must play sports every day."

For the second topic, after group brainstorming and discussion on ideas, it was noted that nearly all students (nineteen out of twenty) could produce clearer main ideas for the topic. For example, Tung Anh wrote the three main ideas "money is the first reason for the break-up of a love... Family is the next reason... The last and most important reason make couple split up is personality". In Ninh's paper, she wrote "family is a reason for the break-up of a love... Job is a reason for the break-up of a love... They do not get on well because they have different personality". Compared with her paper on the first topic, the ideas were clearer. Another case is Nhung's ideas: "You do not understand your boyfriend or girlfriend... Romance can keep love... In love we do not accept a bad person". Some typical examples above indicate that main ideas in the second written papers are more clearly expressed. In other words, main ideas are identified more easily.

Compared with main ideas in preintervention written papers, main ideas in post-intervention ones were also better supported with more details for each idea. Some examples are shown in the following table: 
Table 2. Extracts of students'writing before and after intervention

\begin{tabular}{|c|c|c|}
\hline Student's & Pre-intervention & Post-intervention \\
\hline Hoa & $\begin{array}{l}\text { Firstly, I cook is healthy, } \\
\text { eatn’t food has fat, fast food } \\
\text { and eat vegetable, meat, fish. } \\
\text { Secondly, I often go to walk } \\
\text { (and play tennis), it is help me } \\
\text { comfortable. I play tennis for } \\
\text { good healthy }\end{array}$ & $\begin{array}{l}\text { Money is one of the reasons for the break-up of } \\
\text { a love. Have a lot of money you may forget your } \\
\text { girlfriend. Family is the second reason for the break- } \\
\text { up of a love. It is the conflict between mother in law } \\
\text { and daughter in law. The rich family do not like the } \\
\text { poor family. }\end{array}$ \\
\hline Ninh & $\begin{array}{l}\text { First and most importantly, } \\
\text { you should full eats such as: } \\
\text { vegetable, fish, met... It's good } \\
\text { healthy. You shouldn't eats } \\
\text { ready-prepared food. It very oil } \\
\text { so I can fat. I allway action for } \\
\text { good healthy as: go to walk or } \\
\text { play sports }\end{array}$ & $\begin{array}{l}\text { The job is a reason for the break-up of a love. Her } \\
\text { job is busy, so she don't have enough time for } \\
\text { boyfriend. He earn a few money, so he can't go } \\
\text { shopping, or go to the cinema with girlfriend. So } \\
\text { they break up. The job is reason make break-up of a } \\
\text { love because they do not together. }\end{array}$ \\
\hline Thuong & $\begin{array}{l}\text { Next, breakfast is very important } \\
\text { and you should eat three meals, } \\
\text { vegetable and milks. Finally, you } \\
\text { should sleep from six to eight } \\
\text { hours one day. }\end{array}$ & $\begin{array}{l}\text { Next, family is the second reason for the break- } \\
\text { up of a love. Wealthy families often do not like } \\
\text { poor families or intellectual family does not like } \\
\text { unlettered family. The final, one reason is money. } \\
\text { Because money is the necessary means of life, do not } \\
\text { have money they can not pay daily things. So they } \\
\text { argue and split up. }\end{array}$ \\
\hline
\end{tabular}

Some above examples indicated that group brainstorming activities could improve quality of ideas in students' papers. This was also consistent with the analysis of students' journals and interviews.

"I think that I can write more supporting sentences because when we share our ideas, we explain the ideas so that other people can understand." (Thuong - Interview) "If someone has a different idea, she needs to explain it or other members can help to explain. If the ideas are the same, we explain the ideas together." (Ninh - Journal)

"We develop ideas together and individuals can learn from these ideas to write. I don't remember to use linking words, but one person in my group tells the others." (Tinh Journal)
"I feel that my writing is better, because I have more ideas when sharing and discussing with my peers. I choose better ideas to write and use linking words, because in group we tell each other and remind each other to do so." (Tung Anh - Journal)

\subsubsection{Letter writing}

\section{Quantity of ideas}

The quantity of ideas in letter writing was measured by counting different ideas there were in each student's paper. The first topic was "a letter to apply for an internship position" and the second one was "a letter to apply for a position to work for the forthcoming Olympic Games". The Mean (M) and SD (standard deviation) were accounted to compare the number of ideas in the two written pieces. The High shows the highest number of ideas and the Low shows the lowest number of ideas in students' papers .The results are showed in the following chart: 


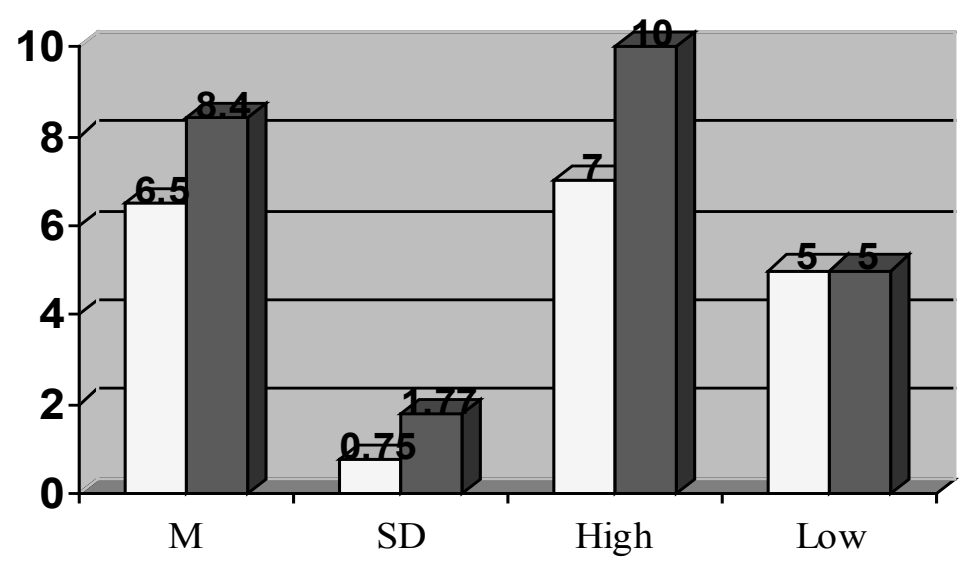

$\square$ Pre-intervention
$\square$ Post-intervention

Figure 4. Ideas in students' letters

The graph shows that after training students produce more ideas in their written papers, with a rise from average 6.5 to 8.4 ideas $(1.3$ times). The highest number of ideas on the first writing topic is seven and the lowest is five, which shows that the difference of number of ideas among students is not much $(\mathrm{SD}=0.75)$. In fact, most students (seventeen students) produced seven ideas including stating the position ("I am writing to apply for the receptionist in IA Hotel"), experience ("I am a qualified...and I have been working at... since..."), languages ("I have good level of English and I also speak..."), and the closing of the letter ("I enclose you my covering letter as requested. I look forward to hearing from you"), which was highly influenced by the sample in the text book. This was consistent with post-interviews with the students:

"I think the letter is a bit short, but I don't know to write other ideas and I'm afraid that the ideas I think more are not suitable, so I just imitate the sample" (Nhung)

"Many of us imitate the sample and make some changes by replacing some words like the position or working place. It's like the form for us to follow, and I think it's safe for us." (Ly)
There was only one piece of writing (Oanh's) in which she mentioned some characteristics of personalities "I am active and enthusiastic" in response to some required personalities from the company advertisement "looking for dynamic, enthusiastic and hardworking people..."

For the second letter writing, before writing students were asked to brainstorm in group on personalities and experience they might need for the position. When comparing the second papers with the first ones, there were more ideas concerning personalities. Students described their personalities needed for the job with one or two sentences which included three to five adjectives of personalities. On the other hand, there were no notable changes in the idea of experience. Similar to the first letter, all of the students wrote one sentence including the job and length of time they did it. An example is "I have worked as a receptionist at $\mathrm{ABC}$ hotel for six months". It could be seen that the number of ideas in parts like the introduction, experience, language, and closing of the letter remained similar to those in the first letters.

\section{Quality of ideas}

When comparing two letters written by the students on quality of ideas, it was seen that there were no important differences in the 
quality of ideas. The comparison of ideas was analyzed as follows.

The first idea was to introduce the position that the applicant is applying for, and all the students could express this idea clearly in both writing. The way students wrote this idea was highly influenced by the one in the sample.

The idea of experience could be supported with some details in the second letters. For instance, in the first letter, most students (fifteen students) just wrote "I have been working as a receptionist since 2013", "I have been working at Thuong Hai Restaurant since December 2011", "I am a tour guide and I have been working at a famous tourism company since June 2011", or "I am a qualified interpreter and I have been working at Galaxy Hotel since 2012". Meanwhile, in the second letter, some students (six students) added details such as "I am the reception of the $A B C$ restaurant in 2009. I have a lot of experience about the services and communication with customer", "I have been working part-time during the summer and I have lots of experience in my job. It is to welcome guess at the hotel.", "I used to work part-time as a waitress. I have experience and I feel confident and comfortable with the job." However, many other students' ideas were still highly influenced by the sample.

The idea of language could be clearer in some students' letters. In the first letter, most of the students (seventeen out of twenty students) wrote "I have good level of English"; some students (six students) added "and I know Chinese/ Russian/ a little Korean". In the second letter, some students wrote supporting ideas. For example, Ly wrote "I have a good level of English. I passed level B1 excellently. I can speak and communicate quite fluently", Quan "I have a good level of written and spoken English. I passed level B1 and I am getting a course of level B2", Trung "I can speak English quite well and I can speak a little Korean". However, it was noted that in many other letters, the expressions were similar to those in the first ones.

The ideas to close the letter: "I enclose you my $\mathrm{CV}$ as requested. I look forward to hearing from you" were the same in both letters. They were also the same as those in the sample letter.

Although there were some differences, the improvements in the quality and quantity of ideas between the two letters were not so significant. In other words, in letter writing, the influences of group brainstorming activities on quantity and quality of ideas in the letters were not clear. In fact, these results were in agreement with analysis of students' journals and post-interviews.

"I hardly make changes to the introduction and the closing of the letter. I don't know how to change so I just remain them, but I think there are no problems with them" (Hoa - Interview)

"I think many parts of this type of letter such as the introduction and the closing can be the same. The introduction is to state the position, so just the name of the position can be replaced." (Quan - Interview) "I think that the letter has its format so we can follow it." (Nhung Journal)

Students like Hoa and Quan admitted that they did not make changes to some parts of the letter. Quan even thought that just some words (like the position) needed changing. In addition, Nhung realized that this type of letter had a fixed format, so they could follow it. In fact, application letter is a type of formal letters which has its typical structure and layout. This type of letter requires appropriate language and content with condense, exact and clear information. Group brainstorming did have some effects on letter writing lesson, 
but not important effects on idea generation. Other effects of group brainstorming activities would be discussed in the next part.

\subsection{Research question 2: How do students} perceive the effectiveness of collaborative brainstorming activities?

Students' perceptions on the effectiveness of group brainstorming activities were synthesized through analysis of students' journals, observations and interviews. The results showed that group brainstorming had some other positive effects on learning.

\subsubsection{Paragraph writing}

Students' perceptions on the effectiveness of group brainstorming in paragraph writing lesson were summarized in the table below. There were twenty students in the class and students' perceptions were analyzed through students' journals and interviews.

Table 3. Students' perception of the effectiveness of group brainstorming in paragraph writing lesson

\begin{abstract}
expressions to apply into my writing." (Tung Anh - Interview)

"I don't know how to express some ideas in English and my group members helps me." (Ninh Interviews)

"It's very good for us to learn and revise vocabulary and sentence structures." (Nhung - Journals)

"I can learn new words from whom I work with." (Hue - Journals)

"My vocabulary to write would be increased if I could continue such group work." (Hanh - Journals)
\end{abstract}

\begin{tabular}{lll}
\hline No & \multicolumn{1}{c}{ Effects of group brainstorming } & Percentage of students \\
\hline 1. & $\begin{array}{l}\text { Prepare more vocabulary, grammar structures and expressions } \\
\text { for students to write. }\end{array}$ & $100 \%$ \\
\hline 2. & Make students stay motivated and interested in the lesson. & $100 \%$ \\
\hline 3. & Make students more focused and work faster. & $75 \%$ \\
\hline 4. & $\begin{array}{l}\text { Make students understand more about each other and improve } \\
\text { solidarity among classmates. }\end{array}$ & $60 \%$ \\
\hline 5. & Help students make better outline for writing. & $50 \%$ \\
\hline 6. & Improve creativity and thinking skills for individuals. & $25 \%$ \\
\hline
\end{tabular}

All students in the class liked group brainstorming activities and everyone gave some positive feedback on the lesson. In paragraph writing, group brainstorming prepared more vocabulary, structures and expressions for students to write. This feedback is the most popular, as it was mentioned in all students' journals, and even confirmed by interviewees:

"Group work helps me to have

more vocabulary, grammar and 
Table 4. Students' perception of the effectiveness of group brainstorming in letter writing lesson

\begin{tabular}{lcc}
\hline No & Effects of group brainstorming & Percentage of students \\
\hline 1. & Make the lesson more interesting. & $100 \%$ \\
\hline 2. & Make students focus on the lesson. & $70 \%$ \\
\hline 3. & Revise vocabulary and grammar. & $60 \%$ \\
\hline 4. & Create interactive learning. & $60 \%$ \\
\hline 5. & Create relaxing learning environment. & $50 \%$ \\
\hline 6. & Improve thinking skills. & $55 \%$ \\
\hline 7. & Improve team work skills. & $55 \%$ \\
\hline
\end{tabular}

In letter writing, the most popular feedback was making the lesson more interesting, which was shown in all journals and post-interviews with the students. Next came making the students stay concentrated on the lesson with $70 \%$. It was understandable because when students liked the lesson, they would focus more on the lesson. Other effects of group brainstorming were improving thinking skills and team work skills, creating interactive learning and relaxing learning environment.

\subsubsection{Problems in group brainstorming}

Besides positive feedback, students mentioned several problems when brainstorming in group.

Firstly, group members did not agree on the choice of words to express ideas in English:

"In my group, when we choose words to express ideas in English, we did not agree with each other about some words. For example, I like the word "hobbies" but others like "favourite". However, we think together how to use each word and when writing the person can use the word she likes" (Hanh - group 2)

"Because we are not sure how to use some words, to express some ideas there could be different words from members. But we write all the words, we think that we could ask the teacher later." (Ly - group 1)
Students were encouraged to express ideas in English, but they could write in Vietnamese. When working together about ideas, group members had different choices of English words to express the ideas. However, they solved the problems by writing all the choices then in individual writing they could choose the word they prefer, or they could consult the teacher. In this case, the rule "no criticizing" could help students to avoid argument.

The next problem was that some members did not work enthusiastically:

"In my group, a member did not take part in group work enthusiastically for a while. However, he was reminded by other members so he worked better." (Hoa - group 1)

One more problem that students mentioned was the time limit of group work sessions:

"I think that the time to work in group is a bit short. I also think that we should have more time to write in group so that weak students can learn more." (Mung)

"If we have more time, we can write in group after combining ideas. I think it will be better." (Lan)

Some students like Mung felt that the group work time was short because students had time to do group brainstorming on ideas but not to write together. Therefore, students suggested that they should have chances to write together in group after group brainstorming. In deed, 
according to the procedure, students wrote individually instead of collaboratively. After the lesson, the students' idea raised another issue of applying collaborative writing after collaborative brainstorming.

\section{Conclusion}

\subsection{Summary of major findings}

Collaborative brainstorming training procedures had signigicant effects on quantity and quality of ideas in students' written papers, and on student's learning of writing skills. Group brainstorming activities remarkably improved quantity and quality of ideas in paragraph writing. However, in letter writing, the changes were not noticeable as students were influenced by models of application letter with its typical expressions. Training also had positive effects on student's learning.

The present study reinforces the findings of previous studies. Training can increase quantity of ideas and the order of brainstorming sessions solitary to group brainstorming is effective (Baruah \& Paulus, 2008). In addition, additional rules, for example writing ideas in Vietnamese, contribute to improving the number of ideas generated in group (Putman \& Paulus, 2009). Students also benefit from paying attention to other's ideas during brainstorming process, increasing overall productivity of the group (Brown \& Paulus, 2002). Regarding learners' perspectives, students find group brainstorming useful and effective in preparing them to write (Rao, 2007; Christmas, 2008). Furthermore, brainstorming could enhance learning motivation and improve learning performance as well as other soft skills for students (Blatchford et al, 2003; Gillies, 2003; Dooly, 2008; Saed, 2011).

The research also makes significant findings about the effectiveness of collaborative brainstorming. The most important one is that training can increase quality of ideas in students' written papers. To be specific, in paragraph writing, intermediate students can improve cohesion and coherence. Next, training students with group brainstorming can enhance quantity and quality of ideas in just some specific writing task type. In the study, group brainstorming had worth noting effects on paragraph writing, but not letter writing. Besides, with the rules in the collaborative brainstorming procedures, free riding and performance matching could be reduced, as group members encourage each other to take part in discussion. Other factors like evaluation apprehension and blocking were not mentioned as problems in group brainstorming. Last, teacher's changed instructions to the lesson plan may contribute to better students' learning performance. These findings may be important for practitioners and further researchers to consider.

\subsection{Contributions of the study}

In terms of methodology, triangulation of different sources of data was essential to analyze the results. In the research, students' written papers were not sufficient to conclude the effectiveness of group brainstorming on the quantity and quality of ideas. The students' journals were valuable sources to investigate student's perceptions on the group brainstorming activities; and the interviews with the students helped to check the consistency and reliability of students' views. Especially, the involvement of a critical colleague is necessary in action research. In my study, the critical colleague helped me to take notes during the lessons and then give feedback on the lessons. More importantly, she discussed some changes to the original lesson plan that contributed to the effectiveness of group brainstorming. From that, group idea selection for writing was raised for further studies. 
In terms of pedagogy, the study explored the effectiveness of collaborative brainstorming procedures as pre-writing activities in a specific teaching context, teaching writing to an intermediate English class. It contributed a model of idea generation training for writing which could be implemented in similar situations. Thus, it helped foster collaborative brainstorming in the field of English language teaching.

\subsection{Limitations of the study}

Despite the researcher's efforts, the study still has some short-comings because of time limitation and other unexpected factors. First, the number of participants was quite small in comparison with the whole number of intermediate students at the university. In fact, since action research is carried out in a class, the number of student participants is limited. Possibly because of this reason, the rates or percentages of students counted in the feedback on the effectiveness of group brainstorming need to be interpreted as statistics in a class with twenty students. In other words, the results should be understood with caution to avoid overgeneralization. Secondly, because of time limitation, group brainstorming procedures were implemented in two writing genres at this level (paragraph writing and letter writing). Thus, the results should not represent all writing task types at intermediate level. If other writing types of the course like story writing, film review were involved in the research, the effectiveness of collaborative brainstorming would be more comprehensive with all specific types.

\section{Acknowlegement}

This article is based on a thesis by the author under the supervision of Dr. Hoang Thi Hanh at VNU University of Languages and International Studies. The author would like to give sincere thanks to Dr. Hoang Thi Hanh for her invaluable support, helpful guidance and considerable encouragement so that the thesis could be completed.

\section{References}

Baruah, J., \& Paulus, B. P. (2008). Effects of training on idea generation in groups. Small Group Research, 39, 523-541. doi: 10.1177/1046496408320049

Bauer, S. (2009). Pre-writing: brainstorming and listing. Sophia. Retrieved from http://www.sophia.org/ tutorials/prewriting-brainstorming/

Berne, J. (2009). The writing-rich high school classroom. New York: Guilfork Press.

Blatchford, P., Kutnick, P., Baines, E., Galton, M., (2003). Toward a social pedagogy of classroom group work. International Journal of Educational Research. 39(1-2), 153-172.

Brown, V. R., \& Paulus, B. P. (2002). Making group brainstorming more effective: Recommendations from an Associative Memory perspective. Current Directions in Psychological Science, 11(6), 208212.

Brown, V. R., \& Paulus, B. P. (1996). A simple dynamic model of social factors in group brainstorming. Small Group Research, 27(1), 91-114.

Brown, V., Tumeo, M., Larey, T. S., \& Paulus, P. B. (1998). Modeling cognitive interactions during group brainstorming. Small Group Research, 29, 495-526.

Christmas, B. (2008). The role of brainstorming in improving student writing performance in the EFL classroom. Retrieved from http://sydney.edu.au/cet/ docs/research/The $\% 20$ Role $\% 20$ of $\% 20$ Brainstorming $\% 20$ in\%20Improving\%20Students\%20Writing

Diehl, M., \& Stroebe, W. (1991). Productivity loss in brainstorming groups: Toward the solution of a riddle. Journal of Personality and Social Psychology, 53, 497-509.

Diehl, M., \& Stroebe, W. (1991). Productivity loss in idea-generating groups: tracking down the blocking effect. Journal of Personality and Social Psychology, 61 (3), 392- 403.

Dooly, M. (2008). Telecollaborative language learning: A guidebook to moderating intercultural collaboration online. Bern: Peter Lang.

Dunnet, M. D., Campbell, J., \& Jastaad, K. (1963). The effect of group participation on brainstorming effectiveness for two industrial samples. Journal of Applied Psychology, 47, 30-37.

Gillies, R. M., (2003). Structuring cooperative group work in classrooms. International Journal of Educational Research, 39(1), 35-49. Retrieved from http://www.sciencedirect.com/science/article/pii/ S0883035503000727

Mullen, B., Johnson, C., \& Salas, E. (1991). Productivity loss in brainstorming groups: A meta-analytic integration. Basic and Applied Social Psychology, 12, 3-24.

Nagasundaram, M., \& Dennis, A. R. (1993). When a group is not a group: The cognitive foundation of 
group idea generation. Small Group Research, 24, 463-489.

Osborn, A. F. (1963). Applied imagination: Principles and procedures of creative problem solving ( $\left.3^{\text {rd }} \mathrm{ed}.\right)$. New York: Scribner.

Paulus, P. B. (2000). Groups, teams, and creativity: the creative potential of idea-generating groups. Applied Psychology: An International Review, 49(2), 237-262.

Paulus, P. B, Dugosh, K. L, Dzindolet, M. T., Coskun, H., \& Putman, V. L (2002). Social and cognitive influences in group brainstorming: Predicting production gains and losses. European Review of Social Psychology, 12, 299-325.

Paulus, P. B., \& Dzindolet, M. T. (1993). Social influence processes in group brainstorming. Journal of Personality and Social Psychology, 64(4), 575-586.

Paulus, P. B., Larey, T. S., \& Ortega, A. H. (1995). Performance and perception of brainstormers in an organizational setting. Basic and Applied Social Psychology, 18, 3-14.
Paulus, P. B., Larey, T. S., Putman, V. L., Leggett, K. L., \& Roland, E. J. (1996). Social influence processes in computer brainstorming. Basic and Applied Social Psychology, 18, 3-14.

Paulus, P. B., Nakui, T., Putman, V. L., \& Brown, V. R. (2006). Effects of task instructions and brief breaks on brainstorming. Group Dynamics: Theory, Research, and Practice, 10, 206-219.

Rao, Z. (2007). Training in brainstorming and developing writing skills. ELT Journal, 61(2), 100-106. doi: $10.1093 / \mathrm{elt} / \mathrm{ccm} 002$

Saed, M. M (2011). The effectiveness of brainstorming on teaching ESPreading at university level. Retrieved from http://www.iasj.net/iasj?func=fulltext\&aId=17650

Stein, M. I. (1975). Stimulating creativity: Vol. 4. Group procedures. San Diego, CA: Academic Press.

\title{
TÍNH HIỆU QUẢ CỦA QUY TRİNH RÈN LUYỆN PHÁT TRIỄN Ý TƯỞNG THEO NHÓM TRƯỚC KHI VIẾT CHO SINH VIÊN TRİNH ĐỘ TIẾNG ANH TRUNG CÂPP
}

\author{
Trần Thị Ánh Tuyết \\ Khoa Tiếng Anh, Truờng Đại học Ngoại ngũ, ĐHQGHN, \\ Phạm Văn Đồng, Cầu Giấy, Hà Nội, Việt Nam
}

Tóm tắt: Bài viết này trình bày kết quả của một nghiên cứu cải tiến sư phạm định tính xuất phát từ thực tiễn giảng dạy tiếng Anh của tác giả cho sinh viên trình độ trung cấp. Nghiên cứu khảo sát ảnh hưởng của quy trình rèn luyện việc thảo luận và phát triển ý tưởng theo nhóm đến khả năng phát triển ý tưởng cho bài viết và việc học kỹ năng viết của sinh viên thông qua phỏng vấn, quan sát lớp học, bài viết và bài báo phản hồi của sinh viên. Nghiên cứu chỉ ra rằng quy trình thảo luận ý tưởng theo nhóm được bổ sung một số quy tắc động não có thể cải thiện số lượng và chất lượng ý tưởng trong bài viết đoạn văn, nhưng không có tác dụng đáng kể đến viết thư. Ngoài ra, thảo luận ý tưởng theo nhóm trước khi viết có tác động tích cực tới việc học kỹ năng viết của sinh viên. Bởi vậy, kết quả của nghiên cứu có đóng góp quan trọng vào việc áp dụng quy trình thảo luận ý tưởng theo nhóm khi dạy tiếng Anh.

Tù khóa: động não, thảo luận ý tưởng theo nhóm, kỹ năng viết, quy tắc động não 